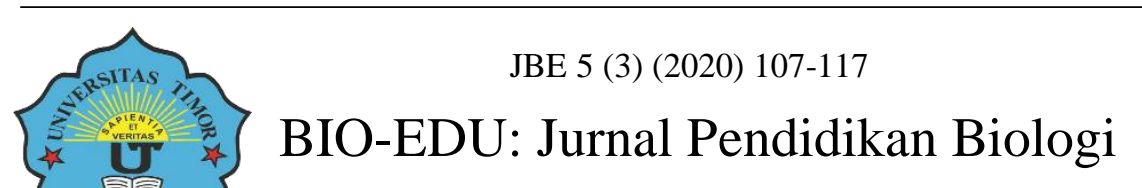

https://jurnal.unimor.ac.id/JBE/index

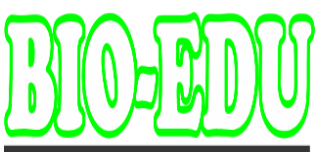

Jurnal Pendidikan Biologi

\title{
Study on Abundance and Distribution Pattern of Collembola on Three Types of Land Utilizations in Banjar Regency, South Kalimantan
}

\section{Studi Kelimpahan dan Pola Sebaran Collembola pada Tiga Tipe Penggunaan Lahan di Kabupaten Banjar, Kalimantan Selatan}

\author{
Manap Trianto, dan Fajri Marisa \\ Departemen Biologi Tropika, Fakultas Biologi, Universitas Gadjah Mada \\ Jl. Teknika Selatan, Senolowo, Sinduadi, Mlati, Sleman, Yogyakarta, Indonesia, 55281 \\ E-mail: manaptrianto@mail.ugm.ac.id
}

\section{DOI: https://DOI 10.32938/jbe. v5i3.606}

\begin{abstract}
Abstrak
Collembola merupakan salah satu organisme tanah yang dikelompokkan sebagai mesofauna. Tujuan penelitian ini adalah untuk mempelajari kelimpahan dan pola sebaran Collembola pada tiga tipe penggunaan lahan di Kabupaten Banjar, Provinsi Kalimantan Selatan. Penelitian ini dilaksanakan pada bulan April 2020 dengan menggunakan metode purposive sampling. Berdasarkan hasil identifikasi jenis Collembola yang didapatkan pada lokasi sampling, terdapat 12 genus, 6 famili, dan 2 ordo Collembola. Kelimpahan tertinggi terdapat pada Perkebunan Kelapa Sawit. Sedangkan pola sebaran Collembola pada tiga tipe pembukaan lahan sama yaitu mengelompok. Hasil penelitian ini diharapkan dapat berkontribusi pada pelestarian dan pemanfaatan salah satu sumber daya keanekaragaman hayati penting Indonesia.
\end{abstract}

Kata Kunci: Kelimpahan; pola sebaran; Collembola; penggunaan lahan; Kalimantan Selatan

\begin{abstract}
Collembola is one of soil organism which classified as mesofauna. This reseach is aims to study the abundance and distribution patterns of Collembola on three types of land utilization in Banjar District, South Kalimantan Province. This research was conducted on April 2020 by using a purposive sampling method. Based on results of Collembola identification obtained at the sampling location, there are 12 genera, 6 families, and 2 orders of Collembola. The highest abundance is found in oil palm plantations. While the Collembola distribution pattern on the three types of land clearing is the same, which is clustering. The results should contribute to the preservation and utilisation of one of Indonesia's important biodiversity resources.
\end{abstract}

Keywords: Abundance; distribution pattern; Collembola; land utilizations; South Kalimantan

\section{PENDAHULUAN}

Ekosistem merupakan suatu sistem dalam skala ekologi yang terbentuk dari adanya interaksi hubungan timbal balik antara mahluk hidup dan lingkungan dengan 
tujuan untuk menunjang kehidupannya (Margono, 2014: 730-735; Trianto et al., 2020: 21-29; Trianto dan Purwanto, 2020: 2619-2628). Tanah sebagai salah satu komponen ekosistem sering didefenisikan sebagai habitat bagi berbagai jenis organisme tanah. Kelimpahan dan pola sebaran organisme tanah yang tinggi dapat menjaga dan menstabilkan keadaan suatu ekosistem khususnya kesuburan tanah itu sendiri (Riyanto, 2007: 241-253; Suheriyanto, 2012: 29-38; Trianto et al., 2020: 199-209). Di alam, organisme tanah banyak memiliki peranan misalnya sebagai dekomposer, memaksimalkan unsur hara tanah, dan menjaga sifat fisik, kimia serta biologi tanah (Pommeresche dan Loes, 2014: 165-179; Suprianto et al., 2020: 30-39). Salah satu organisme tanah yang dimaksud adalah Collembola.

Collembola merupakan salah satu organisme tanah yang dikelompokkan sebagai mesofauna, karena memiliki kelompok yang lebih besar dibanding kedua kelompok lainnya dan mempunyai ukuran tubuh yang relatif kecil yaitu sekitar $0,25 \mathrm{~mm}-8 \mathrm{~mm}$ (Folser, 2002: 234-245; Fachrul, 2012: 58-61). Morfologi Collembola memiliki bentuk tubuh yang bervariasi seperti bundar, oval, pipih, gilik, dan dorso-ventral. Bagian tubuh terdiri dari kepala (mulut, mata, dan antena yang terdiri dari empat ruas), thoraks (protoraks, mesotoraks, dan metatoraks) dan bagian abdomen (terdiri atas enam ruas). Collembola juga memiliki bagian kolofor (collophore) yaitu organ tambahan yang terdapat pada sisi ventral ruas pertama pada abdomen. Selanjutnya pada ruas ketiga terdapat organ tambahan berupa tenakulum. Sedangkan pada ruas keempat terdapat organ tambahan berupa furkula (Hopkin, 2002: 208-210; Suhardjono et al., 2012: 34; Oktaviani et al., 2017: 16-24).

Di dunia tercatat ada sekitar 6.000 spesies dari 500 genus (Suhardjono et al., 2012: 34) yang tersebar dibeberapa negara dan khususnya diberbagai tipe habitat. Di Indonesia sendiri jenis Collembola yang telah berhasil diidentifikasi yaitu sekitar 17 famili, 124 genus dan 250 spesies. Sedangkan dilihat dari tipe habitatnya, Collembola dapat hidup pada habitat vegetasi, tajuk pohon, di dalam tanah, dan permukaan serasah (Husamah et al., 2015: 392-410; Husamah et al., 2016: 45-50; Cahyani et al., 2017: 455-464).

Keberadaan Collembola pada suatu habitat dapat dipengaruhi oleh faktor fisika kimia yaitu suhu, $\mathrm{pH}$, kelembaban, kadar air tanah atau habitat, zat toksik atau pencemar, dan musim atau iklim (Rahmadi et al., 2004: 179-185; Jucevica dan Meleis, 2005: 124126). Fitrahtunnisa dan Ilhamdi (2013: 413-421) melaporkan bahwa kelimpahan Arthropoda tanah berkorelasi dengan faktor-faktor abiotik lingkungan di suatu ekosistem, seperti kandungan bahan-bahan organik tanah, ketebalan lapisan serasah, suhu, kelembaban tanah, dan kandungan air tanah.

Penelitian tentang Collembola telah dilakukan di beberapa wilayah di Indonesia misalnya di Pulau Jawa yaitu Provinsi Jawa Barat (Suhardjono, 2002: 29-38; Erwinda, 2015: 58), Provinsi Jawa Timur (Susanti, 2015: 71), Pulau Bali dan Lombok (Suhardjono, 1992: 104-106), Pulau Sulawesi yaitu Provinsi Sulawesi Tenggara (Suriana et al., 2015: 7-12), Pulau Sumatera yaitu Provinsi Lampung (Fatimah et al., 2012: 17-22), Provinsi Jambi (Widrializa, 2015: 173-180; Warino, 2017: 51-57), Pulau Kalimantan yaitu Kalimantan Timur (Suhardjono, 1985: 104-106), Kalimantan Tengah dan Kalimantan Barat (Rahmadi dan Suhardjono, 2003: 179-185). Sedangkan penelitian Collembola terkait studi kelimpahan dan pola sebaran masih jarang dilakukan.

Provinsi Kalimantan Selatan merupakan salah satu Provinsi di Pulau Kalimantan yang banyak dilakukan kegiatan pembukaan lahan. Proses pembukaan lahan di suatu wilayah dapat berakibat pada penurunan kualitas tanah serta dapat mengganggu kehidupan organisme yang tinggal di wilayah tersebut dan akhirnya akan memberikan 
dampak terhadap penurunan kelimpahan hayati (BPS, 2015: 15; Trianto dan Marisa, 2020: 29-33). Oleh karena itu perlu dilakukan penelitian terkait Collembola sebagai bioindikator keadaan tanah, karena organisme ini sangat sensitif terhadap perubahan habitat, baik secara struktur maupun fungsi komunitas (Suhardjono et al., 2012; Trianto et al., 2020: 154-162; Trianto dan Purwanto, 2020: 186-193). Penelitian ini bertujuan untuk mempelajari kelimpahan dan pola sebaran Collembola pada tiga tipe penggunaan lahan di Kabupaten Banjar, Provinsi Kalimantan Selatan yaitu Perkebunan Karet, Perkebunan Kelapa Sawit, dan Hutan Sekunder. Hasil penelitian ini diharapkan dapat memberikan informasi tentang studi kelimpahan dan pola sebaran Collembola di Provinsi Kalimantan Selatan yang berkaitan dengan faktor lingkungan serta dapat membantu dalam melakukan pengembangan ekosistem yang berkelanjutan.

\section{METODE}

\section{Waktu dan Tempat Penelitian}

Penelitian ini dilaksanakan pada bulan April 2020 pada tiga tipe penggunaan lahan di Kabupaten Banjar, Provinsi Kalimantan Selatan yaitu Perkebunan Karet, Perkebunan Kelapa Sawit, dan Hutan Sekunder dengan menggunakan metode purposive sampling (Bookhout, 1996: 201).

\section{Alat dan Bahan}

Alat yang digunakan yaitu ekstraktor mesofauna, mikroskop stereo, kotak sampel, oven, kamera, sekop, meteran, pinset, kuas kecil, botol sampel, kertas label, dan cawan petri. Bahan yang digunakan yaitu sampel Collembola, alkohol 70\%, dan air.

\section{Pelaksanaan Penelitian}

Penelitian ini terdiri dari tiga tahap yaitu pertama survey lapangan untuk mencari dan menentukan lokasi sampling yang sesuai. Kedua, identifikasi jenis Collembola dengan cara memisahkan sampel berdasarkan ordo, famili dan genus yang dilakukan dengan mengacu pada morfologi Collembola dan berpedoman pada data Borror (1996: 182-243) dan Suhardjono et al., (2012: 34). Ketiga, studi kelimpahan dan pola sebaran Collembola dengan menggunakan persamaan Meyer (1996: 343) untuk indeks kelimpahan dan indeks Morisita (Ludwigs dan Renolds, 1988: 55-79).

\section{Analisis Data}

Jenis Collembola yang didapatkan selanjutnya dihitung indeks kemelimpahannya dengan menggunakan persamaan Meyer (1996):

$$
\begin{aligned}
& \text { Keterangan: } \\
& \mathrm{N} \quad=\text { Jumlah genus Collembola } \mathrm{cm}^{2} \\
& \mathrm{IS} \quad=\text { Rata-rata jumlah individu Collembola } \\
& \mathrm{A} \quad=\text { Luas titik pengambilan sampel }
\end{aligned}
$$$$
\mathrm{N}=\mathrm{IS} / \mathrm{A}
$$

Pola sebaran Collembola di analisis menggunakan indeks Morisita:

$$
\mathrm{Id}=\mathrm{n}((\Sigma \mathrm{xi} 2-\Sigma \mathrm{xi}) /(\Sigma \mathrm{xi}) 2-\Sigma \mathrm{xi}))
$$

Keterangan:

Id = Indeks Morisita

$\mathrm{n} \quad=$ Jumlah seluruh petak ukur

$\mathrm{xi}=$ Jumlah individu Collembola pada petak ukur ke-i

Sedangkan indeks Morisita terstandarisasi dihitung menggunakan persamaan:

$\mathrm{Ip}=0.5+0.5((\mathrm{Id}-\mathrm{Mc}) /(\mathrm{n}-\mathrm{Mc})) \quad ;$ jika Id $\geq \mathrm{Mc}>1$ 


$$
\begin{array}{ll}
\mathrm{Ip}=0.5((\mathrm{Id}-1)-(\mathrm{Mc}-1)) & ; \text { jika } \mathrm{Mc}>\mathrm{Id} \geq 1 \\
\mathrm{Ip}=0.5((\mathrm{Id}-1) /(\mathrm{Mu}-1)) & ; \text { jika } 1>\mathrm{Id}>\mathrm{Mu} \\
\mathrm{Ip}=0.5+0.5((\mathrm{Id}-\mathrm{Mu}) /(\mathrm{Mu})) & ; \text { jika } 1>\mathrm{Mu}>\mathrm{Id}
\end{array}
$$

Selanjutnya pola sebarannya ditunjukkan melalui perhitungan Mu dan Mc yaitu:

$$
\begin{aligned}
& \mathrm{Mu}=\left(\mathrm{x}^{2}{ }_{0.975}-\mathrm{n}+\Sigma \mathrm{xi}\right) /(\Sigma \mathrm{xi})-1 \\
& \mathrm{Mc}=\left(\mathrm{x}_{0.025}^{2}-\mathrm{n}+\Sigma \mathrm{xi}\right) /(\Sigma \mathrm{xi})-1
\end{aligned}
$$

Keterangan:

$\mathrm{Mu} \quad=$ Indeks Morisita pada pola sebaran seragam

Mc = Indeks Morisita pada pola sebaran mengelompok

$\mathrm{x}^{2}{ }_{0.975}=$ Nilai $\mathrm{x}^{2}$ tabel dengan derajat bebas $\mathrm{n}-1$ dan selang kepercayaan $97.5 \%$

$\mathrm{x}^{2} 0.025=$ Nilai $\mathrm{x}^{2}$ tabel dengan derajat bebas $\mathrm{n}-1$ dan selang kepercayaan $2.5 \%$

$\mathrm{n} \quad=$ Jumlah total petak ukur

xi $=$ jumlah ind Collembola pada petak ukur ke-i

Pengelompokkan pola sebaran Collembola menggunakan kriteria yaitu:

Jika Ip $<0 \quad=$ Seragam

Jika Ip $=0 \quad=$ Acak

Jika Ip $>0 \quad=$ Mengelompok

\section{HASIL DAN PEMBAHASAN}

Hasil

\section{Jenis Collembola yang ditemukan}

Berdasarkan hasil identifikasi jenis Collembola yang didapatkan pada lokasi sampling, diperoleh 12 genus dari 6 famili Collembola yaitu Isotomidae, Entomobryidae, Cyphoderidae, Paronellidae, Oncopoduridae, dan Dicyrtomidae, serta 2 ordo Collembola yaitu Symphypleona dan Entomobyromorpha. Total individu Collembola yang didapatkan yaitu 1286 individu. Jumlah Collembola yang didapatkan berdasarkan tipe penggunaan lahan yaitu pada Hutan Sekunder (5 genus, 2 famili dan 1 ordo), Perkebunan Karet ( 7 genus, 4 famili, dan 2 ordo), dan Perkebunan Kelapa Sawit (11 genus, 6 famili, dan 2 ordo) (Gambar 1).

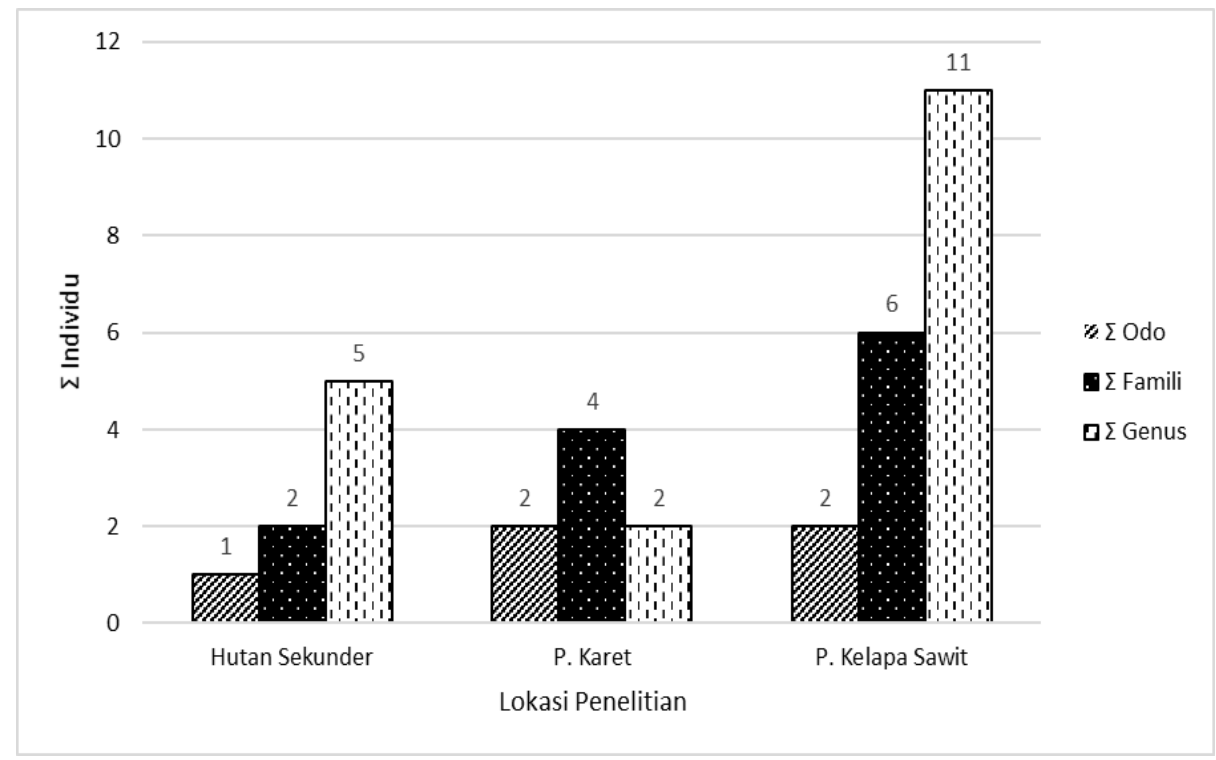

Gambar 1. $\Sigma$ Ordo, Famili, dan Genus Collembola 
Kelimpahan jenis Collembola pada tiga tipe penggunaan lahan

Dalam penelitian ini kelimpahan didapatkan dari $\Sigma$ individu Collembola yang ditemukan pada tiga tipe penggunaan lahan (Tabel 1).

Tabel 1. Kelimpahan jenis Collembola permukaan tanah pada tiga tipe penggunaan lahan

\begin{tabular}{|c|c|c|c|c|c|c|c|c|c|c|c|}
\hline \multirow{2}{*}{ No } & \multirow{2}{*}{ Tipe Habitat } & \multicolumn{9}{|c|}{ Plot contoh } & \multirow{2}{*}{ Total } \\
\hline & & $\mathrm{A} 1$ & A2 & A3 & B1 & B2 & B3 & $\mathrm{C} 1$ & $\mathrm{C} 2$ & $\mathrm{C} 3$ & \\
\hline 1 & Hutan Sekunder & 81 & 35 & 61 & 12 & 9 & 7 & 6 & 10 & 22 & 243 \\
\hline 2 & Perkebunan Karet & 60 & 34 & 38 & 48 & 62 & 53 & 34 & 53 & 32 & 414 \\
\hline 3 & $\begin{array}{l}\text { Perkebunan Kelapa } \\
\text { Sawit }\end{array}$ & 65 & 111 & 66 & 32 & 31 & 159 & 50 & 78 & 46 & 638 \\
\hline \multicolumn{11}{|c|}{ Total } & 1286 \\
\hline
\end{tabular}

Keterangan: A,B, dan C (Plot) \& 1, 2, dan 3 (Ulangan)

Hasil penelitian yang disajikan pada Tabel 1 untuk kelimpahan jenis Collembola permukaan tanah dilokasi penelitian menunjukkan bahwa pada Hutan Sekunder kelimpahan individu Collembola tertinggi pada plot A1 dengan jumlah individu 81, sedangkan kelimpahan terendah terdapat pada plot $\mathrm{C} 1$ dengan jumlah individu 6. Pada habitat Perkebunan Karet kelimpahan tertinggi pada plot B2 dengan jumlah individu 62, sedangkan kelimpahan terendah pada plot C3. Pada habitat Perkebunan Kelapa Sawit, kelimpahan individu Collembola tertinggi pada plot B3 dengan jumlah individu 159, dan kelimpahan terendah terdapat pada plot B2 dengan jumlah individu 31. Kelimpahan jenis tertinggi dalam penelitian ini yaitu terdapat pada habitat Perkebunan Kelapa Sawit sebesar 638 individu Collembola, sedangkan kelimpahan jenis terendah terdapat pada habitat Hutan Sekunder sebesar 243 individu Collembola.

\section{Pola sebaran Collembola permukaan tanah}

Suatu ekosistem terdiri dari tiga pola dasar sebaran yaitu mengelompok, seragam, dan acak (Ludwig dan Reynold, 1988: 55-74). Untuk mengetahui pola sebaran suatu spesies dalam ekosistem atau habitat dapat dilakukan dengan menggunakan berbagai indeks, misalnya dengan rasio varian dan mean, koefisien green, indeks clumping, dan indeks morisita yang telah sesuai dengan standar statistik. Dalam prosesnya, indeks yang sering digunakan untuk mengetahui pola sebaran suatu spesies yaitu indeks morisita. Rani (2003: 1351-1368) menyatakan bahwa indeks morisita merupakan metode terbaik untuk mengukur pola sebaran spasial suatu individu yang tidak bergantung terhadap kepadatan populasi dan ukuran sampel. Dalam penelitian ini, pola sebaran Collembola permukaan tanah pada tiga tipe penggunaan lahan dapat dilihat pada Tabel 2.

Tabel 2. Pola Sebaran Collembola permukaan tanah pada tiga tipe penggunaan lahan

\begin{tabular}{clccccccc}
\hline No & Tipe Habitat & $\Sigma x i$ & $\Sigma x i^{2}$ & $I d$ & $M u$ & $M c$ & $I p$ & Pola Sebaran \\
\hline 1 & Hutan Sekunder & 213 & 45.369 & 1,69 & 0,97 & 1,03 & 0,54 & Mengelompok \\
2 & Perkebunan Karet & 414 & 171.396 & 1,02 & 0,98 & 1,01 & 0,49 & Mengelompok \\
3 & Perkebunan & 638 & 407.044 & 1,18 & 0,98 & 1,01 & 0,51 & Mengelompok \\
& Kelapa Sawit & & & & & & & \\
\hline
\end{tabular}


Keterangan:

$\Sigma x i=$ Total individu Collembola pada petak ke-i

$\Sigma x i^{2}=$ Total kuadrat dari $\Sigma x i$

Id $\quad=$ Indeks morisita

$M u \quad$ = Indeks morisita (Pola sebaran beragam)

$M c \quad=$ Indeks morisita (Pola sebaran mengelompok)

Ip = Indek morisita yang telah berstandarisasi

Tabel 2 menyajikan hasil analisis indeks Morisita, dimana nilai Id tertinggi yaitu pada habitat Hutan Sekunder dengan nilai 1,69. Sedangkan Id terendah terjadi pada habitat Perkebunan Karet dengan nilai 1,02. Pola sebaran Collembola pada tiga tipe penggunaan lahan dalam penelitian ini sama yaitu Mengelompok, hal ini didapatkan dengan cara menghitung nilai sebasar $M u$ dan $M c$. Selanjutnya, nilai yang didapatkan dicocokkan dengan keterangan standarisasi dari indeks morisita.

\section{Pembahasan}

\section{Jenis Collembola yang ditemukan}

Berdasarkan hasil identifikasi jenis Collembola pada tiga tipe pembukaan lahan, diperoleh sekitar $9.68 \%$ genus Collembola dari jumlah total genus yang telah tercatat di Indonesia yaitu 12 dari 124 genus (Greenslide et al., 2000: 171-179). Selanjutnya berdasarkan jumlah ordo yang didapatkan, Entomobryomorpha merupakan ordo dengan jumlah genus dan individu terbanyak yaitu 14 genus, 5 famili, dan 724 individu. Hal ini dapat terjadi karena genus dari ordo Entomobryomorpha memiliki karakteristik aktif bergerak dan proses adaptasi yang cepat dengan didukung oleh bentuk yang ramping dan furkula panjang (Hopkin, 1997: 208-210). Collembola merupakan salah satu jenis organisme permukaan tanah yang tidak memiliki sayap dan pada umumnya tidak aktif berjalan sehingga jangkauannya tidak luas. Pada Collembola, bagian pengganti sayap untuk proses berpindah tempat dinamakan furkula. Karena keterbatasan tersebut membuat sebagian jenis dari Collembola saat ini bersifat sebagai organisme endemik misalnya Collembola dari genus Heteromorus yang tersebar di Indonesia khususnya baru di jumpai di Pulau Sumatera dan Genus Homidia dengan spesies Homidia cingula yang baru tercatat ada di Wai Lima dan Bogor (Suhardjono et al., 2012: 34).

\section{Kelimpahan jenis Collembola pada tiga tipe penggunaan lahan}

Hasil kelimpahan Collembola (Tabel 1) yang didapatkan pada tiga tipe penggunaan lahan pada penelitian ini dapat dikategorikan melimpah. Hal ini dapat terjadi karena dipengaruhi oleh frekuensi kehadiran jenis Collembola pada suatu habitat. Pada habitat dengan karakterisasi (kondisi) yang relatif tetap, akan menghasilkan jumlah jenis Collembola yang tinggi dengan komposisi total individu setiap jenis sedikit. Sebaliknya, pada habitat dengan karakterisasi (kondisi) yang mengalami perubahan secara ekstrim maka akan memiliki komposisi jenis yang sedikit namun jumlah individu dari setiap jenis banyak (Odum, 1971: 176). Hasil penelitian yang didapatkan sesuai dengan pernyataan tersebut, bahwa pada tipe pembukaan lahan pada Perkebunan Kelapa Sawit memiliki jumlah total individu Collembola terbanyak jika dibandingkan dengan tipe penggunaan lahan lainnya yaitu terdapat 633 individu (Tabel 1). Hal ini menunjukkan bahwa perubahan fungsi hutan menjadi non hutan akan mempengaruhi perubahan suatu habitat dan jumlah spesies yang ada di dalamnya, sehingga jika dilihat dari segi ekologis maka 
perubahan tersebut akan merugikan karena dapat menurunkan tingkat keanekaragaman jenis spesies yang ada pada suatu habitat, dalam hal ini adalah jenis Collembola permukaan tanah.

Melimpahnya jumlah individu Collembola yang ditemukan pada tipe pembukaan lahan pada Perkebunan Kelapa Sawit diduga erat kaitannya dengan laju dekomposi, karena Collembola sendiri merupakan salah satu organisme permukaan tanah yang berperan sebagai dekomposer. Peran Collembola sebagai dekomposer bahan organik telah dibuktikan pada penelitian yang dilakukan oleh Lawrence dan Wise (2000: 33-39) bahwa seiring dengan berkurangnya jumlah predator ternyata dapat meningkatkan jumlah populasi Collembola dan sekaligus dapat meningkatkan laju dekomposi serasah pada permukaan tanah hutan. Sebagai informasi tambahan, Warino (2017: 51-57) menyatakan bahwa sekitar $27,6 \%$ daun kelapa sawit terdiri atas kandungan lignin. Tingginya kandungan lignin pada daun kelapa sawit akan berpengaruh pada laju proses dekomposisi serasah sehingga diperlukan organisme dekomposer yang lebih banyak dalam prosesnya.

Dibandingkan dengan hasil penelitian sebelumnya yang dilakukan oleh Ritaqwin (2018: 17) pada tipe penggunaan lahan yang berbeda dengan penelitian ini yaitu pada Hutan Primer, Semak Belukar, dan Hutan Paska Bakar diperoleh hasil kelimpahan Collembola yang berbeda dan bervariasi pada setiap tipe penggunaan lahannya. Hal ini dapat terjadi dikarenakan setiap penggunaan lahan memiliki karakteristik yang berbeda. Amir (2008: 16-17) menyatakan, bahwa kelimpahan dan keanekaragaman jenis Collembola berkaitan erat dengan kemampuan individu dalam menyesuaikan diri terhadap perubahan lingkungan maupun ketersediaan sumber makanan. Jumlah serasah yang dihasilkan pada suatu wilayah akan mempengaruhi kelimpahan Collembola. Oktavianti et al. (2017: 16-24), meyatakan bahwa tanah yang banyak terdapat serasah akan menyebabkan Collembola menjadi aktif melakukan proses penguraian untuk menjadi humus. Hal ini didukung oleh pernyataan Indriyanti dan Wibowo (2008: 110116), Collembola umumnya dikenal sebagai fauna yang hidup di tanah dan memiliki peranan penting sebagai perombak bahan organik tanah.

\section{Pola sebaran Collembola permukaan tanah}

Pola sebaran merupakan salah satu hal yang penting bagi organisme dalam suatu wilayah, habitat atau komunitas ekologi. Hal ini merupakan kajian dasar atau tahapan awal dalam mengetahui keadaan suatu komunitas atau kelompok organisme. Terbentuknya suatu pola sebaran organisme dalam suatu habitat baik secara seragam, mengelompok atau acak dpat terjadi karena dipengaruhi oleh beberapa faktor misalnya faktor vektorial (disebabkan dari gabungan beberapa faktor lingkungan), faktor sosial (berkaitan dengan perilaku organisme), faktor reproduksi (berkaitan dengan model reproduksi dari suatu organisme), faktor koaktif (dihasilkan dari interaksi intraspesifik), dan faktor stokastik (dihasilkan dari kombinasi faktor vektorial, sosial, reproduksi, dan koaktif) (Rani, 2003: 1351-1368).

Pola sebaran Collembola sendiri terjadi karena dipengaruhi oleh adanya angin, air, feromon, kegiatan manusia, dan yang terpenting kondisi lingkungan atau habitat (Suhardjono et al., 2012: 34). Dalam penelitian ini, Collembola yang ditemukan sebagian bersifat sebagai kosmopolitan atau daya adaptasi yang tinggi dengan lingkungan baru. Berdasarkan habitatnya, Collembola dapat hidup selamanya di dalam tanah (eudafik), hidup di dalam tanah dan serasah (hemiedufik), dan hidup di atas permukaan tanah (atmobiotik) (Suhardjono et al., 2012: 34). Hasil penelitian menunjukkan bahwa 12 genus 
Collembola yang ditemukan pada tiga tipe pembukaan lahan, semuanya hidup pada serasah dan tanah.

Berdasarkan hasil analisis pola sebaran menggunakan indeks morisita pada populasi Collembola, diperoleh hasil bahwa pola sebaran mengelompok pada ketiga tipe pembukaan lahan yaitu Hutan Sekunder, Perkebunan Karet, dan Perkebunan Kelapa Sawit. Hal ini menunjukkan bahwa Collembola yang didapatkan hidup secara berkmpul sesuai dengan habitat dan kebutuhannya (Rani, 2003: 1351-1368). Pola sebaran yang didapatkan dalam penelitian ini juga menandakan bahwa tiga tipe pembukaan lahan dalam penelitian ini masih toleran terhadap kebutuhan hidup atau masih bisa menunjang kehidupan Collembola.

Selanjutnya dilihat dari proses perkembangbiakannya, kecepatan reproduksi pada Collembola merupakan salah satu faktor yang dapat mendukung pola sebarannya. Hal ini sesuai dengan pernyataan Suhardjono et al. (2012: 34) bahwa dalam kurun waktu yang cepat ( $\pm 2,5$ menit) Collembola mampu menghasilkan telur yang banyak $( \pm 850$ telur) dengan pola mengelompok pada permukaan serasah atau tanah dan akan menetas dalam rantan waktu 10-15 hari pada suhu normal lingkungan. Hal ini merupakan salah satu faktor pendukung yang membuat pola sebaran Collembola pada suatu habitat mengelompok, karena pada dasarnya dalam proses peletakan telur sudah tersusun secara mengelompok. Sedangkan apabila dilihat dari perilaku sosialnya, Collembola bersifat agregasi. Hal ini dapat terjadi karena adanya pengaruh dari lingkungan dan karena adanya feromon agregasi yang dapat mengakibatkan persebarannya mengelompok (Hopkin, 1997: 208-210). Agregasi yang terjadi memungkinkan Collembola satu dan lainnya untuk menuju dan hidup pada habitat yang sama.

\section{KESIMPULAN DAN SARAN}

\section{Kesimpulan}

Berdasarkan analisis data Collembola pada tiga tipe pembukaan lahan di Kabupaten Banjar, Kalimantan Selatan diketahui bahwa kelimpahan tertinggi terdapat pada Perkebunan Kelapa Sawit yaitu 638 individu. Selanjutnya, pola sebaran Collembola pada tiga lokasi penelitian sama yaitu mengelompok.

\section{Saran}

Perlu dilakukan penelitian lanjutan mengenai kelimpahan dan pola sebaran Collembola pada tipe penggunaan lahan lainnya di Provinsi Kalimantan Selatan, khususnya pada tingkat genus sampai spesies karena informasi tersebut dirasa masih kurang. Dalam hal pengelolaan lahan sebaiknya keberadaan serasah tidak perlu dibersihkan, karena hal tersebut dapat mendukung produktivitas lahan secara berkelanjutan khususnya kelimpahan Collembola.

\section{DAFTAR RUJUKAN}

[BPS] Badan Pusat Statistik. (2015). Luas daerah dan jumlah pulau menurut provinsi 2015. BPS.

Amir, A.M. (2008). Peran serangga ekor pegas (Collembola) dalam rangka meningkatkan kesuburan tanah. Badan Penelitian dan Pengembangan Pertanian. Pusat Penelitian dan Pengembangan Perkebunan. Warta, 14(1), 16-17. 
Bookhout, T.A. (1996). Research And Management Techniques For Wildlife And Habitats. Kansas (US): Allen Press Inc.

Borror, D.J., Charles, A.T., \& Norman, F.J. (1996). Pengenalan Pelajaran Serangga. Partosoedjono. S. Penerjemah. Yogyakarta (ID): Gadjah Mada University Press. Terjemahan dari: An Introduction to Study of Insect.

Cahyani, K., Aminatun, T., \& Putra, N.S. (2017). Struktur komunitas Collembola di lingkungan rhizosfer Chromolaena odorata pada lahan vulkanik, pantai berpasir dan karst. J. Prodi Biologi, 6(8), 455-464.

Erwinda. (2015). Dinamika populasi dan keanekaragaman Collembola pada tanaman kelapa sawit di perkebunan Cikasungka Kabupaten Bogor. [Tesis]. Bogor (ID): Institut Pertanian Bogor.

Fachrul, M.F. (2012). Metode Sampling Bioekologi. Edisi 1 Cetakan III. Jakarta: Bumi Aksara.

Fatimah, Cholik, E., \& Suhardjono, Y.R. (2012). Collembola permukaan tanah kebun karet, Lampung. Zoo Indonesia, 21(2), 17-22.

Fitrahtunnisa, \& Ilhamdi, M.L. (2013). Perbandingan keanekaragaman dan predominansi fauna tanah dalam proses pengomposan sampah organik. J. Bumi Lestari, 13(2), 413421.

Folser, J. (2002). The role of Collembola in Carbon and Nitrogen Cycling in Soil. $J$. Pedobiologia, 46(3-4), 234-245.

Greenslade, P., \& Vaughan, G.T. (2003). A comparison of Collembola species for toxicity testing of Australian soils. Pedobiologia, 47, 171-179.

Hopkin, S.P. (1997). Collembola. In: Lal R(Ed). Encyclopedia of Soil Scince. New York (US): Marcel Dekker Inc. p. 208-210.

Hopkin, S.P. (2002). Collembola. In: Lal R(Ed). Encyclopedia of Soil Scince. New York (US): Marcel Dekker Inc. p. 208-210.

Husamah, Fatchur, R., \& Hedi, S. (2015). Pengaruh C-organik dan kadar air tanah terhadap jumlah jenis dan jumlah individu Collembola sepanjang daerah aliran sungai Brantas Kota Batu. J. Symbion, 392-410

Husamah, Rohman, F., \& Sutomo, H. (2016). Struktur komunitas Collembola pada tiga tipe habitat sepanjang daerah aliran sungai Brantas Hulu Kota Batu. Bioedukasi, 9(1), 45-50.

Indriyati, \& Wibowo, L. (2008). Keragaman dan kemelimpahan Collembola serta Arthopoda di lahan sawah organic dan konvensional pada masa bera. J. HPT Tropika, 8(2), 110-116.

Juceviva, E., \& Meleis, V. (2005). Long-term effect of climate warning on forest soil Collembola. Acta Zoological Lituanica, 15, 124-126.

Lawrence, K.L., \& Wise, D.H. (2000). Spider predation on forest-floor Collembola and evidence for indirect effect on decomposition. Pedobiologia, 44(1), 33-39.

Ludwig, J.A., \& Reynolds, J.F. (1988). Statistical Ecology: A primer method and computing. New York (US): John Wiley and Sons Inc.

Margono, B.A., Potapov, P.V., Turubanova, S., Stolle, F., \& Hansen, M.C. (2014). Primary forest cover loss in Indonesia over 2000-2012. Nature Clim Change, 4, 730735.

Meyer, E. (1996). Mesofauna.In : Schinner E, Ohlinger R, Kandeler E, Margesin R, editor. Methods in Soil Biology. Berlin (DE): Springer-Verla. p. 343.

Odum, E.P. (1971). Fundamentals of Ecology. Philadelphia (US): WB Sounders Company Ltd. 
Oktavianti, R., Nurdin, J., \& Herwina, H. (2017). Komunitas Collembola pada hutan konservasi dan perkebunan sawit di kawasan PT. Tidar Kerinci Agung (TKA), Sumatera Barat. J.Biologi Universitas Andalas, 5(1), 16-24.

Pommeresche, R., \& Loes, A.K. (2014). Diversity and density of Springtails (Collembola) a grass-clover ley in North-West Norwy. Norwegian Journal of Entomology, 61, 165179.

Rahmadi, C., \& Suhardjono, Y.R. (2003). Keanekaragaman Arthropoda tanah di lantai hutan kawasan hulu Sungai Katingan Kalimantan Tengah. Berita Biologi, 6(4), 549554.

Rahmadi, C., Suhardjono, Y.R., \& Andayani, I. (2004). Collembola lantai hutan kawasan Sungai Tabalong Kalimantan Selatan. Biota IX, 3, 179-185.

Rani, C. (2003). Metode pengukuran dan analisis pola spasial (dispersi) organisme bentik. Jurnal Protein, 19, 1351-1368.

Ritaqwin, Z. (2018). Studi keanekaragaman Collembola di Kalimantan Barat. [Tesis]. Bogor (ID): Institut Pertanian Bogor.

Riyanto. (2007). Kepadatan, pola distribusi dan peranan semut pada tanaman di sekitar lingkungan tempat tinggal. Jurnal Penelitian Sains, 10(2), 241-253.

Suhardjono, Y.R. (1985). Perbandingan populasi serangga permukaan lantai Hutan Wanariset, Kalimantan Timur. Berita Biologi, 3(3), 104-106.

Suhardjono, Y.R. (1992). Fauna Collembola tanah di Pulau Bali dan Pulau Lombok. [Disertasi]. Depok (ID): Universitas Indonesia.

Suhardjono, Y.R. (2002). Keanekaragaman fauna tanah di Cikaniki, Taman Nasional Gunung Halimun. Research and Conservation of Biodiversity in Indonesia, 9, 34-43.

Suhardjono, Y.R., Deharveng, L., \& Bedos, A. (2012). Biologi-Ekologi-Klasifikasi Collembola (EkorPegas). Bogor (ID): Vegamedia.

Suheriyanto, D. (2012). Keanekaragaman fauna tanah di Taman Nasional Bromo Tengger Semeru sebagai bioindikator tanah bersulfur tinggi. Saintis, 2(1), 29-38.

Suprianto, Trianto, M., Alam, N., \& Kirana, N.G.A.G.C. (2020). Karakter morfologi dan analisis daerah conserved gen elongation factor 1a (EF1a) pada Lepidotrigona terminata. Jurnal Metamorfosa, 7(2), 30-39.

Suriana, Amirullah, \& Wahyuni. (2015). Kelimpahan Collembola permukaan tanah di daerah perkebunan masyarakat di Desa Lalowiu Kecamatan Konda Kabupaten Konawe Selatan Provinsi Sulawesi Tenggara. BioWallaceae, 2(2), 7-12.

Susanti, S.F. (2015). Keanekaragaman dan kelimpahan Collembola tanah pada lahan kapur PT Semen Indonesia Tbk. Di Tuban, Jawa Timur [Tesis]. Bogor (ID): Institut Pertanian Bogor.

Trianto, M., \& Marisa, F. (2020). Diversity of bees and wasp (Hymenoptera) in cowpea (Vigna sinensis L.) in agricultural area at Martapura District, Banjar Regency, South Kalimantan. Journal of Science and Technology, 9(2), 29-33.

Trianto, M., \& Purwanto, H. (2020). Molecular phylogeny of stingless bees in the Special Region of Yogyakarta revealed using partial 16S rRNA mitochondrial gene. Buletin Peternakan, 44(4), 186-193.

Trianto, M., \& Purwanto, H. (2020). Morphological characteristics and morphometrics of Stingless Bees (Hymenoptera: Meliponini) in Yogyakarta, Indonesia. Biodiversitas, 21(6), 2619-2628. 
Trianto, M., Kaini, Saliyem, Warsih, E., \& Winarsih. (2020). Keanekaragaman serangga polinator pada tanaman nanas (Ananas comosus (L.) Merr.) di Desa Bincau. Jurnal Penelitian Science dan Pendidikan, 9(2), 154-162.

Trianto, M., Marisa, F., \& Siswandari, N.P. (2020). Kelimpahan nisbi, frekuensi, dan dominansi jenis lalat di beberapa Pasar Tradisional di Kecamatan Martapura. Jurnal Metamorfosa, 7(2), 21-29.

Trianto, M., Marisa, F., \& Sukmawati. (2020). Keanekaragaman jenis rayap pada perkebunan kelapa sawit dan perkebunan karet di Kabupaten Banjar, Kalimantan Selatan. Jurnal Biologi Makassar, 5(2), 199-209.

Warino, J., Widyastuti, R., Suhadrjono, Y.R., \& Nugroho, B. (2017). Keanekaragaman dan kelimpahan Collembola pada perkebunan kelapa sawit di Kecamatan Bajubang, Jambi. J. Entomologi Indonesia, 14(2), 51-57.

Widrializa, Widyastuti, R., Santosa, D.A., \& Djajakirana, G. (2015). The diversity abudance of springtail (Collembola) on forest and smallholder in Jambi. J.Trop Soil, 2(3), 173-180. 